\title{
Analisis Pengaruh Profil Toko Resmi Smartphone pada Situs E-Commerce terhadap Tingkat Penjualan
}

\author{
Jessica Aurelia Nadine ${ }^{1}$, Ikhwan Jauhar ${ }^{2}$, Alifa Rizki Rahmarani ${ }^{3}$, Nur Aini Rakhmawati ${ }^{4}$ \\ Institut Teknologi Sepuluh Nopember \\ e-mail: ${ }^{1}$ jsicaarn@gmail.com, ${ }^{2}$ ikhwan.jauhar@gmail.com, ${ }^{3}$ alifa.17052@mhs.its.ac.id, \\ ${ }^{4}$ nur.aini@is.its.ac.id
}

Diajukan: 7 November 2020; Direvisi: 30 November 2020; Diterima: 30 November 2020

\begin{abstract}
Abstrak
Pertumbuhan internet ekonomi di Indonesia telah meningkat 4 kali lipat sejak 2015 dengan tingkat pertumbuhan rata-rata $49 \%$ per tahun. E-commerce merupakan salah satu sektor internet ekonomi di Indonesia yang unggul, terutama dengan adanya salah satu startup unicorn Tokopedia. Selain menjadi startup unicorn di Indonesia, Tokopedia merupakan salah satu e-commerce yang masuk peringkat 10 besar situs e-commerce yang sering dikunjungi per kuarter kedua tahun 2020 bersama dengan Shopee. Sebuah merek sering kali membuka toko di situs e-commerce yang berbeda, hal tersebut untuk memperoleh dan mempertahankan lebih banyak konsumen. Adanya persaingan antara merek smartphone maupun situs ecommerce yang digunakan dapat menjadi masalah karena dapat mempengaruhi tingkat penjualan produknya. Pada penelitian ini, akan dilakukan analisis profil toko, yaitu jumlah pengikut, total penjualan, rating toko, dan persentase repons chat terhadap lima merek smartphone di dua e-commerce berbeda dengan metode kualitatif. Hasil dari penelitian menunjukkan bahwa terdapat dua kategori dari profil toko yang berpengaruh terhadap tingkat penjualan produk, yaitu rating toko, dan jumlah followers.
\end{abstract}

Kata kunci: Analisis penjualan, Analisis profil toko, E-commerce.

\begin{abstract}
Economic internet growth in Indonesia has quadrupled since 2015 with an average growth rate of $49 \%$ per year. E-commerce is one of the leading economic internet sectors in Indonesia, especially with the presence of one of the unicorn startups, Tokopedia. Tokopedia is also one of the e-commerce sites that are in the top 10 frequently visited e-commerce sites in Indonesia per second quarter of 2020 along with Shopee. A brand usually opens a store on different e-commerce to gain and retain more customers. The existence of competition between smartphone brands and e-commerce sites could be a problem because it can affect the level of sales products. In this study, five brands of smartphone merchants' profile regarding the number of followers, total sales, merchants' rating, and chat-response performance on the different $e$ commerce will be analyzed with a qualitative method. The result of this study indicates that there are two categories of merchant profiles that affect the level of product sales, namely the merchants' rating and the number of followers.
\end{abstract}

Keywords: E-commerce, Merchant's profile analysis, Sales analysis.

\section{Pendahuluan}

Pertumbuhan internet ekonomi di Indonesia telah meningkat 4 kali lipat sejak 2015 dengan tingkat pertumbuhan rata-rata 49\% per tahun[1]. Berdasarkan e-Conomy SEA 2019 [1], internet ekonomi meliputi 5 sektor, yaitu: online travel, online media, ride hailing, e-Commerce, dan digital financial services. Indonesia unggul pada sektor ride hailing dan e-commerce dengan adanya startup unicorn seperti Tokopedia, Bukalapak, Gojek, dan Traveloka [1]. Selain menjadi startup unicorn di Indonesia, Tokopedia merupakan salah satu $e$-commerce yang masuk peringkat 10 besar situs $e$-commerce yang sering dikunjungi per kuarter kedua tahun 2020, dengan Tokopedia berada di peringkat kedua [2]. Sementara peringkat pertama situs e-commerce yang sering dikunjungi adalah Shopee [2]. Meskipun demikian, pada penelitian ini menggunakan Tokopedia dan Shopee sebagai obyek penelitian dikarenakan kelengkapan profil toko yang ditampilkan di tiap toko online. Jumlah sesi pengguna yang membuka aplikasi e-commerce mencapai 30 miliar selama 6 bulan terakhir [1]. Hal ini didukung dengan adanya data dari BPS pada tahun 2018 yang 
menunjukkan bahwa jumlah transaksi $e$-commerce di Indonesia mencapai 24,82 juta transaksi dengan nilai transaksi mencapai 17,21 triliun rupiah [3].

E-commerce dapat didefinisikan sebagai semua bentuk transaksi perdagangan barang atau jasa yang dilakukan secara elektronik[4]. Menurut Suyanto dalam proceedings Rahmidani [5], berdasarkan sifat transaksinya, terdapat empat macam penggolongan e-commerce yaitu:

1. Business to business (B2B), merupakan model e-commerce dengan perusahaan sebagai pelaku bisnisnya, sehingga proses transaksi dan interaksinya adalah antara satu perusahaan dengan perusahaan lainnya.

2. Business to Consumer (B2C), merupakan model e-commerce dengan melibatkan langsung antara penjual (penyedia jasa e-commerce) dengan individual buyers atau pembeli sebagai pelaku bisnis.

3. Consumer to Consumer (C2C), merupakan model e-commerce di mana penjual yang berinteraksi adalah perorangan atau individu dan bertransaksi langsung dengan pembeli sebagai individu lain.

4. Consumer to Business (C2B), merupakan model e-commerce dengan perorangan atau individual sebagai pelaku bisnis melakukan transaksi atau berinteraksi dengan suatu atau beberapa perusahaan.

Berdasarkan jenis penggolongan e-commerce tersebut, Tokopedia dan Shopee termasuk dalam kategori Business to Consumer atau dapat disebut juga sebagai marketplace. Marketplace merupakan sebuah pasar elektronik yang melakukan kegiatan menjual dan membeli suatu barang atau jasa yang meliputi tiga aspek, yaitu B2B, B2C, dan C2C [6].

Setiap toko online yang terdaftar di suatu marketplace memiliki informasi yang ditampilkan di halaman tokonya. Informasi tersebut dapat berupa:

1. Jumlah followers, yaitu banyaknya user yang mengikuti toko online.

2. Rating, merupakan rata-rata penilaian pembeli terhadap pelayanan yang dilakukan oleh penjual barang melalui toko online.

3. Respons chat, adalah seberapa cepat respons penjual terhadap pertanyaan yang disampaikan oleh pembeli dalam hitungan menit.

Sebuah merek sering kali membuka toko di situs e-commerce yang berbeda, hal tersebut untuk memperoleh dan mempertahankan lebih banyak konsumen melalui e-commerce. Pada penelitian ini, lima merek smartphone yang memiliki toko di tiga e-commerce menjadi obyek penelitian, yaitu Samsung, Realme, Xiaomi, Oppo, dan Vivo. Setiap toko dari merek smartphone tersebut memiliki tingkat penjualan produk, followers, rating, dan respons chat yang berbeda. Guna memunculkan rasa percaya dari pelanggan terhadap tokonya, indikator-indikator tersebut ada baiknya untuk ditampilkan sebagai faktor penentu yang dipertimbangkan dalam mempengaruhi niat membeli[7]. Selain itu, tingkat kepercayaan atau trust seorang pelanggan dapat menentukan minat beli karena merupakan bentuk loyalitas pelanggan[8]. Meningkatnya minat beli seorang pelanggan tentunya bersifat paralel dengan tingkat penjualan.

Jika pada penelitian sebelumnya berfokus pada pengaruh kepercayaan (trust) pembeli dalam melakukan transaksi online, penelitian ini berfokus pada analisis penjualan merek smartphone di $e$ commerce yang berbeda berdasarkan profil toko. Analisis akan dilakukan untuk mengetahui apakah jumlah pengikut, rating, dan respons chat dapat mempengaruhi tingkat penjualan di suatu e-commerce. Adanya penelitian ini diharapkan dapat membantu pihak toko maupun e-commerce untuk mengatasi permasalahan yang menyebabkan perbedaan tingkat penjualan masing-masing toko online.

\section{Metode Penelitian}

Metode yang digunakan dalam penelitian ini adalah dengan menggunakan metode kualitatif yaitu studi literatur pada beberapa jurnal yang berkaitan dengan penjualan di marketplace dan melakukan pengamatan terhadap 2 marketplace dengan 5 toko yang berbeda dari kategori smartphone.

Gambar 1 mengilustrasikan alur metode penelitian yang akan digunakan dengan penjabaran sebagai berikut:

\subsection{Pengumpulan Data dan Informasi}

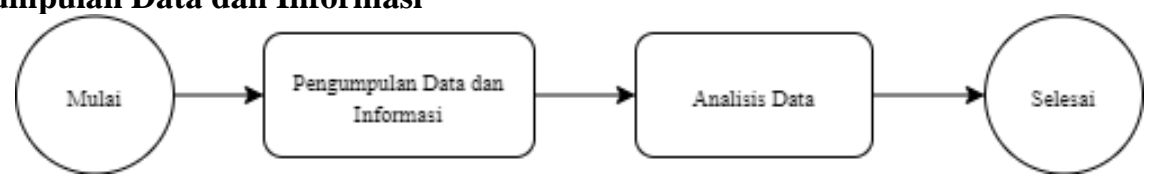

Gambar 1. Alur metode penelitian. 
Teknik pengumpulan data yang digunakan adalah observasi. Observasi menurut Morris pada Syamsudin [9] adalah aktivitas mencatat suatu gejala dengan bantuan intsrumen untuk mencatat guna tujuan ilmiah atau lainnya. Dalam penelitian ini, pengumpulan data dilakukan dengan cara mengamati profil lima toko smartphone yang didaftarkan pada dua kanal e-commerce yaitu Shopee dan Tokopedia. Berdasarkan hasil observasi yang dilakukan pada tanggal 21 Oktober 2020, didapatkan data profil lima toko smartphone yang terletak pada Tabel 1. Observasi profil lima toko smartphone kategori penjualan smartphone pada Tokopedia. (kanal e-commerce Tokopedia), Tabel 2. Observasi profil lima toko smartphone kategori penjualan smartphone pada Shopee (kanal e-commerce Shopee).

Tabel 1. Observasi profil lima toko smartphone kategori penjualan smartphone pada Tokopedia.

\begin{tabular}{clccccc}
\hline \multirow{2}{*}{ No } & \multirow{2}{*}{ Kategori } & \multicolumn{4}{c}{ Tokopedia } \\
\cline { 2 - 6 } & Total Penjualan & $24.1 \mathrm{~K}$ & $31.8 \mathrm{~K}$ & $16.3 \mathrm{~K}$ & $35.4 \mathrm{~K}$ & $\mathbf{E}$ \\
\hline 1 & Rating & $4.9(10169)$ & $4.9(12755)$ & $4.9(8168)$ & $4.9(15238)$ & $4,8(3423)$ \\
\hline 2 & 5 menit & 25 menit & 10 menit & 4 menit & 28 menit \\
\hline 3 & Performa Chat & $144 \mathrm{~K}$ & $90.1 \mathrm{~K}$ & $105.1 \mathrm{~K}$ & $121.3 \mathrm{~K}$ & $46.7 \mathrm{~K}$ \\
\hline 4 & Follower (orang) & 38 & 7 & 19 & 48 & 38 \\
\hline 5 & Lama Bergabung (bulan) & & & & & D \\
\hline
\end{tabular}

Tabel 2. Observasi profil lima toko smartphone kategori penjualan smartphone pada Shopee.

\begin{tabular}{|c|c|c|c|c|c|c|}
\hline \multirow{2}{*}{ No } & \multirow{2}{*}{ Kategori } & \multicolumn{5}{|c|}{ Shopee } \\
\hline & & $\mathbf{A}$ & B & $\mathbf{C}$ & D & $\mathbf{E}$ \\
\hline 1 & Total Penjualan & $47,31 \mathrm{~K}$ & $74 \mathrm{~K}$ & $46 \mathrm{~K}$ & $37,4 \mathrm{~K}$ & $4,5 \mathrm{~K}$ \\
\hline 2 & Rating & $4.9(184,4 \mathrm{RB})$ & $4.9(302,7 \mathrm{RB})$ & $4,8(80,7 \mathrm{RB})$ & $4.8(81,7 \mathrm{RB})$ & $4,8(15,5 \mathrm{RB})$ \\
\hline 3 & $\%$ Performa Chat & 100 & 100 & 100 & 100 & 99 \\
\hline 4 & Follower (orang) & $758,1 \mathrm{RB}$ & $978,8 \mathrm{RB}$ & $900,3 \mathrm{RB}$ & $843,4 \mathrm{RB}$ & $319,2 \mathrm{RB}$ \\
\hline 5 & Lama Bergabung (bulan) & 33 & 33 & 23 & 48 & 36 \\
\hline
\end{tabular}

Tabel 3. Keterangan merek smartphone.

\begin{tabular}{cc}
\hline Toko & Merek Smartphone \\
\hline A & Samsung \\
\hline B & Xiaomi \\
\hline C & Realme \\
\hline D & Oppo \\
\hline E & Vivo \\
\hline
\end{tabular}

\subsection{Analisis}

Data yang dikumpulkan merupakan data yang langsung diambil melalui toko resmi ke-5 merek smartphone yang terdapat pada Shopee maupun Tokopedia per November 2020 untuk selanjutnya dilakukan analisis. Analisis data dilakukan dengan membuat grafik dari data yang tersedia menggunakan Excel guna menjawab permasalahan dari penelitian. Hasil olahan data dan informasi yang dianalisis kemudian dielaborasi sehingga dapat memberikan wawasan baru dan informasi yang bermakna bagi penelitian.

\subsection{Penarikan Kesimpulan}

Setelah didapatkan hasil analisis, dilakukan penarikan kesimpulan untuk menjawab pengaruh jumlah pengikut, rating, dan respons chat terhadap tingkat penjualan di suatu e-commerce. Kesimpulan yang didapatkan berupa hal-hal penting yang diperoleh dari perbandingan profil masing-masing toko online yang terdaftar di dua situs e-commerce (Tokopedia dan Shopee).

\section{Hasil dan Pembahasan}

Hasil analisis yang dilakukan terhadap data profil 5 toko merek smartphone yang berbeda di 2 situs e-commerce disajikan dalam bentuk grafik [10] dan dapat dilihat pada Gambar 2 sampai Gambar 15. 


\subsection{Analisis Profil Toko pada Tokopedia}

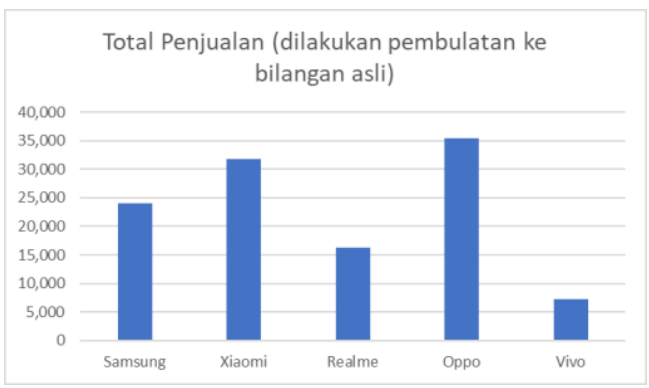

Gambar 2. Total penjualan toko online di Tokopedia.

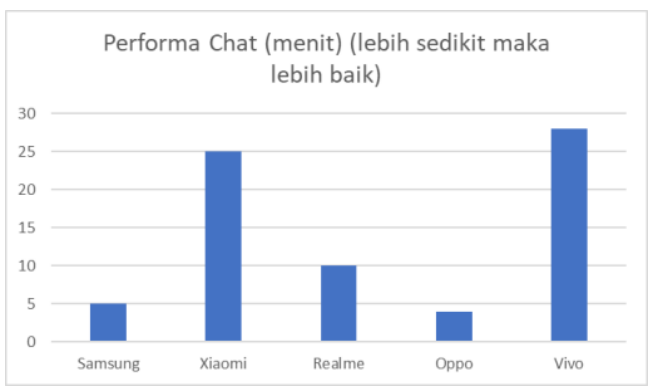

Gambar 4. Performa chat toko online di Tokopedia.

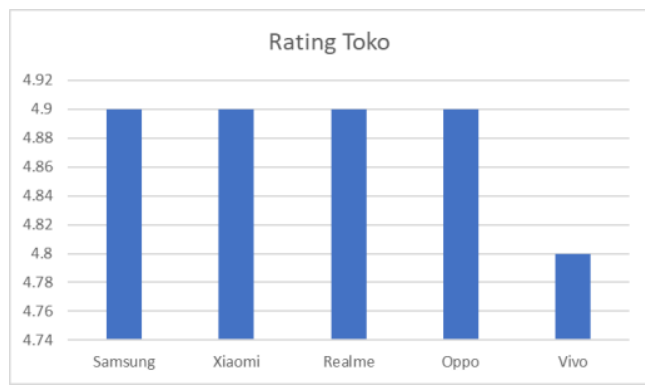

Gambar 3. Rating toko online di Tokopedia.

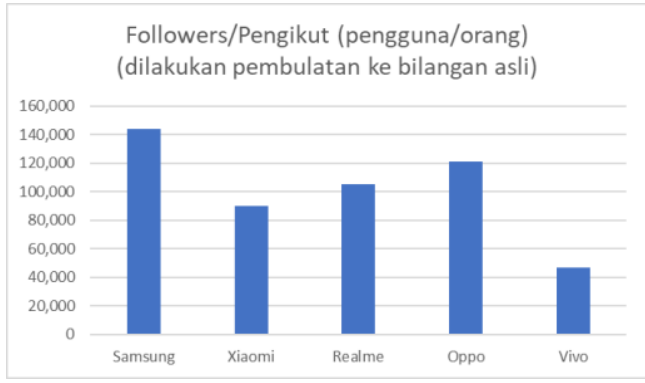

Gambar 5. Jumlah followers toko online di Tokopedia.

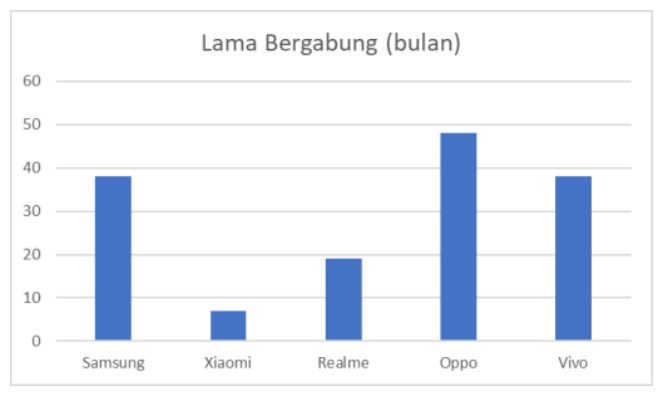

Gambar 6. Lama bergabung toko online di Tokopedia.

\subsubsection{Analisis Rating Toko terhadap Tingkat Penjualan Produk}

Berdasarkan rating toko pada Gambar 3. dan tingkat penjualan toko smartphone pada Gambar 2, dapat dilihat bahwa rating dan total penjualan tertinggi dipegang oleh Oppo, yaitu rating sebesar 4.9 dengan total penjualan sebanyak 35.400. Sementara tingkat penjualan ketiga merek smartphone lainnya yang memiliki rating toko 4.9 menyusul pada peringkat ke-2 sampai 4 dengan penjualan terendah sebesar 16.300. Smartphone merek Vivo memiliki rating toko terendah diantara keempat merek smartphone lainnya, yaitu sebesar 4.8 dan total penjualan terendah jika dibandingkan dengan keempat merek smartphone lainnya, yaitu sebanyak 7.200. Hal tersebut dapat menunjukkan bahwa rating toko dapat mempengaruhi tingkat penjualan produk dari toko smartphone.

\subsubsection{Analisis Performa Chat terhadap Tingkat Penjualan Produk}

Berdasarkan performa chat toko smartphone pada Gambar 4. Dan tingkat penjualan toko smartphone pada Gambar 2, dapat dilihat bahwa performa chat terbaik dan total penjualan tertinggi dipegang oleh Oppo, yaitu performa chat selama 4 menit dan total penjualan sebesar 35.400. Performa chat terbaik kedua dipegang oleh Samsung. Namun, tingkat penjualan produk oleh Samsung sebanyak 24.100 masih kalah jika dibandingkan dengan tingkat penjualan Xiaomi, yaitu sebanyak 31.800 yang memiliki performa chat nomor dua terendah dari kelima merek smartphone, yaitu selama 25 menit. Performa chat merek smartphone Realme masih lebih baik jika dibandingkan dengan Xiaomi, yaitu selama 10 menit. Walaupun demikian, tingkat penjualan Realme masih lebih rendah jika dibandingkan dengan Xiaomi, yaitu 
sebanyak 16.300. Merek smartphone Vivo memiliki performa chat terlama jika dibandingkan dengan keempat merek smartphone lainnya dan memiliki tingkat penjualan produk terendah, yaitu sebanyak 7.200. Walaupun toko smartphone dengan performa chat terbaik memiliki tingkat penjualan tertinggi, dan toko smartphone dengan performa chat terlama memiliki tingkat penjualan terendah, namun terdapat toko smartphone dengan performa chat terlama kedua dengan tingkat penjualan tertinggi kedua. Sehingga berdasarkan analisis tersebut, performa chat tidak begitu berpengaruh terhadap tingkat penjualan produk.

\subsubsection{Analisis Jumlah Followers terhadap Tingkat Penjualan Produk di Tokopedia}

Berdasarkan jumlah followers toko smartphone pada Gambar 5. dan tingkat penjualan toko smartphone pada Gambar 2, jumlah followers toko smartphone dipegang oleh Samsung, yaitu sebanyak 144.000 orang. Walaupun Samsung memiliki jumlah followers terbanyak di antara keempat merek smartphone lainnya, tingkat penjualan produk terbanyak dipegang oleh Oppo. Hal ini dapat menunjukkan bahwa jumlah followers terbanyak belum tentu memiliki tingkat penjualan tertinggi pula. Jumlah followers toko smartphone terendah dipegang oleh Vivo sebanyak 46.700 orang dengan tingkat penjualan terendah pula, yaitu sebesar 7.200. Walaupun banyaknya jumlah followers tidak terlalu berpengaruh terhadap tingkat penjualan tertinggi, jumlah followers masih dapat dijadikan bahan pertimbangan terhadap tingkat penjualan setelah melihat analisis perbandingan jumlah folowers dan tingkat penjualan Vivo yang menduduki peringkat terakhir.

\subsubsection{Analisis Durasi Bergabung terhadap Tingkat Penjualan Produk di Tokopedia}

Berdasarkan durasi lama bergabung toko smartphone pada Gambar 6 dan tingkat penjualan toko smartphone pada Gambar 2, Oppo merupakan merek smartphone dengan durasi bergabung paling lama, yaitu 48 bulan dan tingkat penjualan tertinggi sebanyak 35.400. Lamanya durasi bergabung belum tentu berpengaruh terhadap tingkat penjualan suatu merek smartphone. Hal ini dapat dibuktikan dengan adanya Xiaomi yang memiliki durasi bergabung paling singkat, yaitu 7 bulan namun memiliki tingkat penjualan terbanyak kedua sebanyak 31.800 dan Vivo yang memiliki durasi bergabung sama dengan Samsung, yaitu 38 bulan, namun memiliki tingkat penjualan paling sedikit, yaitu sebanyak 7.200.

\subsection{Analisis Profil Toko pada Shopee}

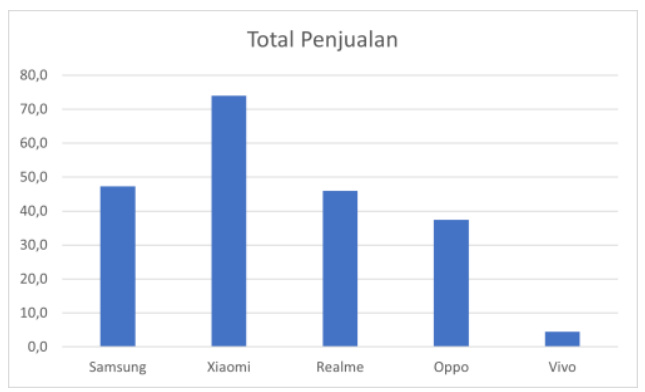

Gambar 7. Total penjualan toko online di Shopee.

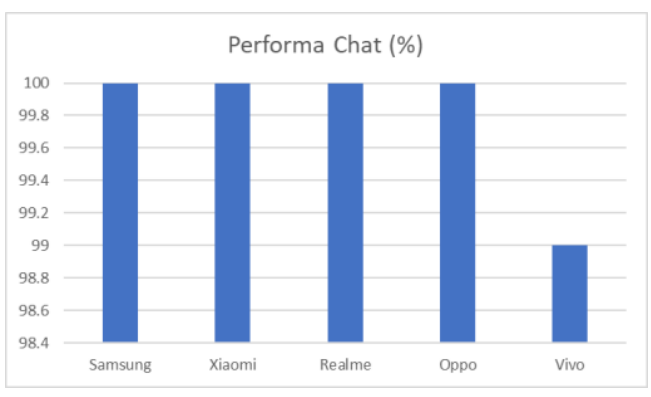

Gambar 9. Performa chat toko online di Shopee.

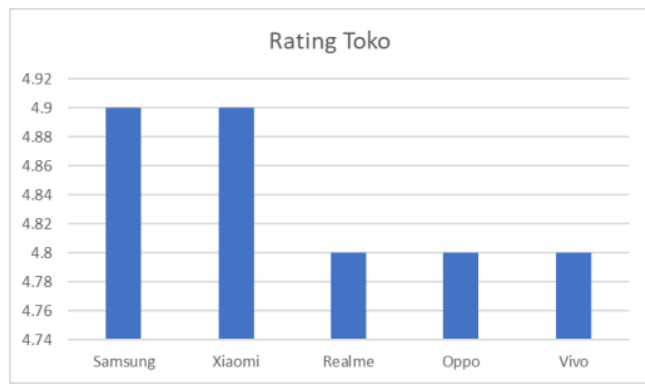

Gambar 8. Rating toko online di Shopee.

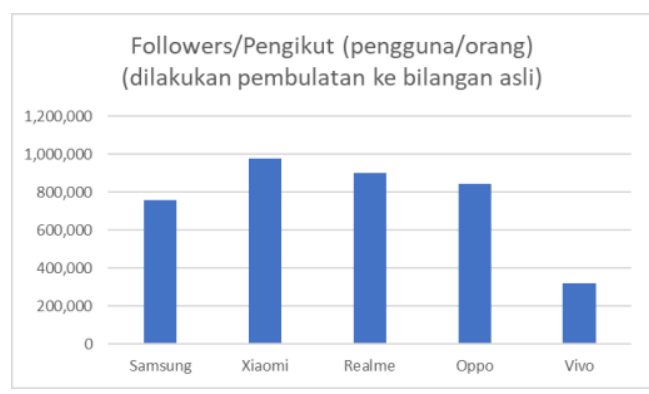

Gambar 10. Jumlah followers toko online di Shopee. 


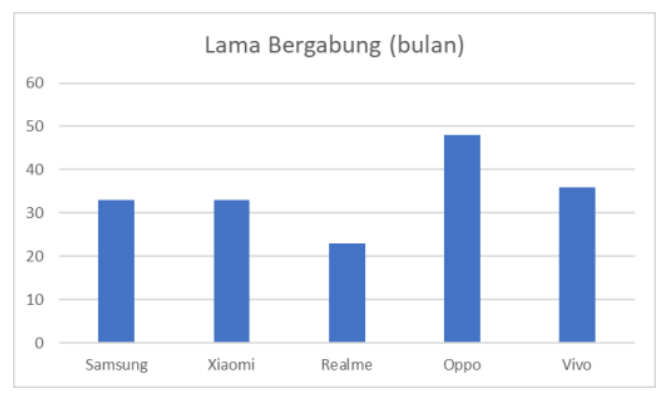

Gambar 11. Lama bergabung toko online di Shopee.

\subsubsection{Analisis Rating Toko terhadap Tingkat Penjualan Produk di Shopee}

Berdasarkan rating toko pada Gambar 8. dan tingkat penjualan toko smartphone pada Gambar 7, Xiaomi memiliki rating toko tertinggi sebesar 4.9 dan tingkat penjualan tertinggi sebanyak 74.000. Samsung memiliki rating toko yang sama dengan Xiaomi, yaitu 4.9 dan memiliki tingkat penjualan tertinggi kedua sebanyak 47.310. Peringkat ketiga dari rating toko dipegang oleh Realme, Oppo, dan Vivo sebesar 4.8. Tingkat penjualan Realme dan Oppo tidak terlalu jauh dengan penjualan Xiaomi dan Samsung yang memiliki rating lebih tinggi. Walaupun demikian, tingkat penjualan Vivo terendah di antara keempat merek smartphone lainnya, yaitu sebanyak 4.500. Hal ini menunjukkan bahwa rating toko masih berpengaruh terhadap tingkat penjualan produk di toko smartphone tersebut.

\subsubsection{Analisis Performa Chat terhadap Tingkat Penjualan Produk di Shopee}

Berdasarkan performa chat toko pada Gambar 9 dan tingkat penjualan toko smartphone pada Gambar 7, tingkat performa chat terbaik, yaitu 100\% dengan tingkat penjualan produk tertinggi sebanyak 74.000 dipegang oleh Xiaomi. Samsung, Realme, dan Oppo juga memiliki persentase performa chat terbaik, yaitu $100 \%$. Performa chat dan tingkat penjualan terendah dipegang oleh Vivo, yaitu sebanyak 4.500, dengan performa chat $99 \%$.

\subsubsection{Analisis Jumlah Followers terhadap Tingkat Penjualan Produk di Shopee}

Berdasarkan jumlah followers toko smartphone pada Gambar 10 dan tingkat penjualan toko smartphone pada Gambar 7, jumlah followers dan tingkat penjualan produk di Shopee dipegang oleh Xiaomi dengan jumlah followers 978.800 orang dan tingkat penjualan sebanyak 74.000. Realme memiliki jumlah followers terbanyak kedua setelah Xiaomi, namun untuk tingkat penjualan terbanyak kedua dipegang oleh Samsung, yaitu sebanyak 47.310. Sementara jumlah followers terendah dan tingkat penjualan terendah dipegang oleh Vivo, yaitu jumlah followers sebesar 319.200 orang dengan jumlah penjualan produk sebanyak 4.500. Berdasarkan analisis tersebut, jumlah followers masih dapat dijadikan sebagai bahan pertimbangan untuk dapat meningkatkan penjualan produk.

\subsubsection{Analisis Durasi Bergabung terhadap Tingkat Penjualan Produk di Shopee}

Berdasarkan durasi bergabung toko smartphone pada Gambar 11 dan tingkat penjualan toko smartphone pada Gambar 7, Oppo telah bergabung selama 48 bulan di Shopee, menjadikan merek ini merek terlama yang menjual produk smartphone nya melalui Shopee. Walaupun demikian, jumlah penjualan tertinggi dipegang oleh Xiaomi, di mana penjualan produk Oppo berada di peringkat ke-4 sebanyak 37.400. Vivo merupakan merek smartphone dengan durasi bergabung yang cukup lam jika dibandingkan dengan Samsung, Realme, dan Oppo, yaitu selama 36 bulan, namun memiliki tingkat penjualan produk yang terendah, yaitu sebanyak 4.500. Berdasarkan analisis tersebut, durasi lamanya bergabung suatu merek belum tentu berpengaruh terhadap tingkat penjualan.

\subsection{Pembahasan}

Berdasarkan analisis profil toko, yaitu pada rating toko, performa chat, jumlah followers, dan durasi bergabung toko yang dilakukan terhadap tingkat penjualan produk pada 5 merek smartphone di 2 situs e-commerce yang berbeda, maka didapatkan hasil sebagai berikut :

1. Rating Toko

Berdasarkan analisis yang dilakukan terhadap rating toko baik di Tokopedia maupun Shopee terhadap kelima merek smartphone tersebut, menunjukkan bahwa terdapat hubungan antara rating toko dengan tingkat penjualan smartphone. 
2. Performa Chat

Berdasarkan analisis yang dilakukan terhadap performa chat baik di Tokopedia maupun Shopee terhadap kelima merek smartphone tersebut menunjukkan bahwa performa chat tidak begitu berpengaruh terhadap tingkat penjualan smartphone.

3. Jumlah Followers

Berdasarkan analisis yang dilakukan terhadap jumlah followers baik di Tokopedia maupun Shopee terhadap kelima merek smartphone tersebut menunjukkan bahwa jumlah followers masih memiliki pengaruh terhadap tingkat penjualan smartphone.

4. Durasi Bergabung

Berdasarkan analisis yang dilakukan terhadap durasi bergabung toko smartphone di Tokopedia maupun Shopee menunjukkan bahwa durasi bergabung belum berpengaruh terhadap tingkat penjualan suatu produk smartphone

Berdasarkan uraian keterkaitan masing-masing kategori dalam profil toko dengan tingkat penjualan suatu produk pada merek smartphone di situs $e$-commerce, maka terdapat dua kategori dari profil toko yang dapat berpengaruh terhadap tingkat penjualan suatu produk smartphone, yaitu rating toko dan jumlah followers toko.

\section{Kesimpulan}

Berdasarkan penelitian yang telah dilakukan, dapat disimpulkan bahwa hasil penelitian ini menunjukkan bahwa terdapat dua kategori dari profil toko yang dapat berpengaruh terhadap tingkat penjualan produk smartphone, yaitu rating dan jumlah followers. Sementara dua kategori lainnya, yaitu durasi bergabung dan performa chat masih belum menunjukkan adanya pengaruh terhadap tingkat penjualan produk smartphone. Perlu dilakukan penelitian lebih lanjut untuk mengetahui adanya kemungkinan bahwa durasi bergabung dan performa chat dapat mempengaruhi tingkat penjualan suatu produk smartphone.

\section{Daftar Pustaka}

[1] Google; Temasek; Bain\&Company, "e-Conomy SEA 2019 : Swipe up and to the right : Southeast Asia's $\$ 100$ billion internet economy,” 2019.

[2] Statista, "Top 10 e-commerce sites in Indonesia as of 2nd quarter 2020, by monthly traffic," Statista $\begin{array}{llll}\text { Research Department, } & \text { [Online]. Available: }\end{array}$ https://www.statista.com/statistics/869700/indonesia-top-10-e-commerce-sites/. [Accessed: 21Oct-2020].

[3] Badan Pusat Statistik, Statistik E-Commerce 2019. Badan Pusat Statistik, 2019.

[4] J. Jauhari, "Upaya pengembangan usaha kecil dan menengah (UKM) dengan memanfaatkan ecommerce," J. Sist. Inf., vol. 2, no. 1, pp. 1-12, 2010.

[5] R. Rahmidani, "Penggunaan E-Commerce Dalam Bisnis Sebagai Sumber Keunggulan Bersaing Perusahaan,” J. SNEMA-Padang-Indonesia, no. c, pp. 345-352, 2015.

[6] P. Artaya and T. Purworusmiardi, "Efektifitas Marketplace Dalam Meningkatkan Konsentrasi," no. April, 2019, doi: 10.13140/RG.2.2.10157.95206.

[7] G. Kim and H. Koo, "The causal relationship between risk and trust in the online marketplace: A bidirectional perspective," Comput. Human Behav., vol. 55, pp. 1020-1029, Feb. 2016, doi: 10.1016/j.chb.2015.11.005.

[8] R. Wibowo, "Kesuksesan E-commerce (OnlineShopping) Melalui Trust Dan Customer Loyalty," Ekon. Bisnis, vol. 20, no. 1, pp. 8-15, 2015.

[9] A. Syamsudin, "Pengembangan Instrumen Evaluasi Non Tes (Informal) untuk Menjaring Data Kualitatif Perkembangan Anak Usia Dini," J. Pendidik. Anak, vol. 3, no. 1, 2015, doi: 10.21831/jpa.v3i1.2882.

[10] J. A. Nadine, I. Jauhar, A. Rahmarani, and N. A. Rakhmawati, "Dataset Profil Toko," Zenodo, 2020. [Online]. Available: https://zenodo.org/record/4164980\#.X6U7dGgzbSE. 